\title{
Bovine spongiform encephalopathy, persistent organic pollutants, and the achievable utopias
}

Does it make much sense to ask your butcher whether a piece of beef contains the bovine spongiform encephalopathy prion protein? I doubt it. Essentially-but not solely, as explained below-because it is unlikely that any prion would be found, even if an efficient test to detect it was available for use on a daily basis. By contrast, it is perfectly sensible to ask your butcher, grocer, or supermarket manage how much the meat, fish, or milk you buy harbour environmental chemical agents such as the pesticide residue DDE, polychlorinated biphenyls, hexachlorobenzene, or hexachlorocyclohexane, which comprise the bulk of persistent organic pollutants in humans. ${ }^{1}$ We largely absorb such chemicals through a wide variety of foods, and most of us store them in fat tissues. ${ }^{2-9}$ Ubiquitous throughout the planet, persistent organic pollutants are a true symbol of "globalisation": they travel through the airs and waters as fast as through the global goods' distribution channels. And they travel through our blood.

That doesn't mean we should not care about bovine spongiform encephalopathy. Sure, serious encephalopathy related issues remain unsolved; notably, the potential link between prion contaminated food and variant Creutzfeldt-Jakob disease. However, while persistent organic pollutants exposure is widespread throughout the Earth (firm evidence, see references $\left.{ }^{1-6}\right)$, exposure to bovine spongiform encephalopathy prions seem much lower on that scale (evidence indeterminate). And sure, the politics of "mad cow disease ${ }^{\prime 1}{ }^{10}$ But we are a bit tired of blaming liberalism's laissez faire, aren't we? So, any ideas for long term global and local politica action? Here we go: one achievable utopia. Like what, specifically? Like global public health governance: dream it, make it real. ${ }^{11}$ On what, precisely? On persistent organic pollutants contamination, for example, on prion free food. ${ }^{13} 14$

Not so easy done, right? Sure, not at all easy. Plus: should we really care? Scientific uncertainties are abundant... Many are shared by bovine spongiform encephalopathy and persistent organic pollutants; for instance, will low dose exposures induce significant individual, population, and environmental ef fects? The question is too vague. (Utopian dreamers are welcome, but with real dreams, please). Today the scientific evidence on bovine spongiform encephalopathy and per sistent pollutants effects-clinical and cultural effects, short-term and long term-is kind of inverse for the two exposures. The short-term cultural effects (and economic, and political) of the encephalopathy have been huge. Not at all the case with persisten pollutants. The long term clinical effects (and cultural, economic, political) of persistent organic pollutants may well be immense.

Yet, not much in the headlines on persistent organic pollutants, compared with the cows. How come, if the evidence is here? Yes, evidence is quite suggestive-not nightmare- that the low dose, long term biological effects of persistent organic pollutants may be real. ${ }^{18}$ 15-17 "Long term" meaning that persistent organic pollutants will persist in humans and the environment for decades. "Effects" meaning: developmental, neurological, mental; cancer promoting effects, hormo- nal and immunological disruption. We're talking tremors, learning disabilities, congenital defects, infertility. We're talking scientific evidence. ${ }^{16}{ }^{15-20}$-not dreams, not nightmares.

That doesn't mean we do not care about bovine spongiform encephalopathy. Low as it might be, the encephalopathy related risk of variant Creutzfeldt-Jakob disease concerns anyone interested in public health. And anyone interested in the social construction of risks. If nothing else, because the evidenceall evidence-is crystal clear on another common feature between persistent pollutants and bovine spongiform encephalopathy: there's little you as an individual can do to escape exposure. No matter how shaky or stout scientific proof is on a causal link between variant Creutzfeldt-Jakob disease and dietary patterns. ${ }^{21}{ }^{22}$ No matter how weak or strong you think scientific proof is on the individual and environmental effects of persistent pollutants: very little you or your grocer can do to avoid risks.

So, who made us think otherwise? (ask our butcher, change our diet, etc). Why the fears, the illusions, the bewilderment? There is such a strong pressure towards privatising risks..23 My risk of variant Creutzfeldt-Jakob disease? From eating this or that? No risk from persistent pollutants? $?^{24} 25$ These risks are socially constructed. It doesn't really matter how little epidemiological evidence has played in shaping them - so much for epidemiology. The fears are real. ${ }^{26}$ Societies in fear: an anti-utopia. And the fears are ecological: direct result of belonging to a certain society at a given time. So, where is public health in all this? Has global public health governance become a utopia?

Well, European policies do tackle global public health issues concerning food safety and health, don't they?27 ${ }^{28}$ Indeed, the political machinery of the European Union is bursting and cracking: trying to cope, in particular, with citizens' annoyance at how our economies produce, manipulate and distribute food, at how we treat animals and the environment. ${ }^{10121}$ Because we know that more "food crises" are in the pipeline, ${ }^{13}{ }^{14}$ we worry. And we wonder whether the bovine spongiform encephalopathy crisis and the persistent organic pollutants non-crisis may lead to structural, "glocal" changes in agricultural, food, industrial and environmental policies. ${ }^{6} 10111426$

But worring is of little service if we hardly know where we want to go. Truly alternative proposals, scenarios, and targets do exist ${ }^{29} ;$ but they entice just some subgroups of citizens. We need a much more articulate, intelligible and seductive picture of what we wish to eat, drink, and breathe -us and our descendents. We must find better ways to dream and draw real utopias.

Different as they are, bovine spongiform encephalopathy and persistent organic pollutants have common roots and implications: political, economic, cultural... But the fact is that the structural changes needed to get rid of prions and persistent pollutants are not very high on the social agenda $a^{29}$ - much as they would help prevent all sorts of public health and environmental crises. Many efforts of public health and ecology are failing because we barely permeate the social imagi- nation. Human health and ecological targets ${ }^{30}$ will hardly be achieved unless we seduce the hearts and minds of our fellow citizens. Real changes in food and environmental policies will not occur unless public health and ecology help draw utopias that entice citizens. Sorry to say: whoever did it for them, the cows did pretty well, in terms of impacting the social agendas. And of course, they did badly. But we're doing pretty bad as well. We talk risks, prions, pollutants. We say so little about the dreams, and so softly, and out of tune. About the real dreams, the achievable utopias...

\section{Acknowledgement}

I am grateful to Tim Lang, Joan Benach, Ana M García, and Ekhine Zumeta for their criticisms to earlier versions of this paper.

\section{Miquel Porta}

Institut Municipal d'Investigació Mèdica (IMIM) Universitat Autònoma de Barcelona, Spain, and School of Public Health, University of North Carolina at Chapel Hill, USA

Correspondence to: Professor M Porta, Institut Municipal d'Investigació Mèdica, Universitat Autònoma de Barcelona, Carrer del Dr Aiguader 80, E-08003 Barcelona, Spain; mporta@imim.es

\section{References}

1 Hansen LG. Stepping backward to improve assessment of $\mathrm{PCB}$ congener toxicities. Environ Health Perspect 1998;106 (suppl 1):171-89.

2 DeVoto E, Kohlmeier L, Heeschen W. Some dietary predictors of plasma organochlorine concentrations in an elderly German population. Arch Environ Health 1998:53:147-55.

3 Liem AK, Furst P, Rappe C. Exposure of populations to dioxins and related compounds. Food Addit Contam 2000;17:241-59.

4 Schepens PJ, Covaci A, Jorens PG, et al. Surprising findings following a Belgian food contamination with $\mathrm{PCB}$ s and dioxins. Environ Health Perspect 2001;109:101-3.

5 Schafer KS, Kegley SE, Patton S. Nowhere to hide. Persistent toxic chemicals in the US food supply. 2nd edn. San Francisco: Pesticide Action Network North America \& Commonwealth, 2001. (http:// www.panna.org/resources/documents/ nowhereToHideAvail.dv. html) (last accessed 25 April 2002)

6 McMichael AJ. Dioxins in Belgian feed and food: chickens and eggs. J Epidemio Community Health 1999;53:742-3.

7 Kalantzi OI, Thomas GO, Alcock RE, et al. The global distribution of PCBs and organochlorine pesticides in butter. Environ Sci Technol 2001;35:1013-18.

8 Porta M, Kogevinas M, Zumeta E, et al. Concentraciones de compuestos tóxicos persistentes en la población española: el rompecabezas sin piezas y la protección de la salud pública. Gac Sanit 2002;16:257-66. (http://db.doyma.es/ cgi-bin/wdbcgi.exe/doyma/ mrevista.fulltext?pident=13032395) (last accessed 21 August 2002).

9 Porta M, Malats N, Jariod M, et al. Serum concentrations of organochlorine compounds and K-ras mutations in exocrine pancreatic cancer. Lancet 1999:354:2125-9.

10 McKee $M$, Lang T, Roberts JA. Deregulating health: policy lessons from the BSE affair. JR Soc Med 1996;89:424-6.

11 Kickbusch I. Global + local = glocal public health. J Epidemiol Community Health 1999;53:451-52. 
12 Bettcher D Lee K. Glossary: Globalisation and public health. J Epidemiol Community Health 2002;56:8-17.

13 McMichael AJ. Bovine spongiform encephalopathy: its wider meaning for population health. BM 1996;312:1313-14

14 Lang T. The new globalisation, food and health: is public health receiving its due emphasis? J Epidemiol Community Health 1998:52:538-9.

15 Kaiser J. Endocrine disrupters. Panel cautiously confirms low-dose effects. Science 2000;290:695-7.

16 Kaiser J. Hazards of particles, PCBs focus of Philadelphia meeting. Science 2000;288:424-5.

17 Brouwer A, Longnecker MP, Birnbaum LS, et al. Characterization of potential endocrine-related health effects at low-dose levels of exposure to PCBs. Environ Health Perspect 1999;107 (suppl 4):639-49.
18 Kogevinas $M$. Human health effects of dioxins: cancer, reproductive and endocrine system effects. Human Reproduct Update 2001;7:331-9.

19 Ribas-Fitó N, Sala M, Kogevinas $M$, et al. Polychlorinated biphenyls (PCBs) and neurological development in children: a systematic review. J Epidemiol Community Health 2001:55:537-46.

20 van Wendel de Joode B, Wesseling C, Kromhout $\mathrm{H}$, et al. Chronic nervous-system effects of long-term occupational exposure to DDT. Lancet 2001;357:1014-16.

21 Morabia A Porta $M$. Ethics of ignorance: lessons from the epidemiological assessment of the implications for humans of the Bovine Spongiform Encephalopathy ("Mad cow disease") epidemic. Perspect Biol Med 1998:41:259-66.

22 Venters GA. New variant Creutzfeldt-Jakob disease: the epidemic that never was. $B M$ 2001;323:858-61.
23 Rockhill B. The privatization of risk. Am J Public Health 2001;91:365-8.

24 Steinberg FM. It is time to dismiss calls to ban DDT. BM 2001;322:676.

25 Pianin E. Dioxin report by EPA on hold. Industries oppose finding of cancer link, urge delay. Washington Post 2001;April 12:A01.

26 van Oyen $H$. Dioxin in feed and food: is public health running behind? J Epidemiol Community Health 1999:53:744-5.

27 Richards T. Health issues rise up the EU agenda. BM 2001;323:772.

28 Watson R. Arguments delay setting up of European food agency. BM 2001;322:1509.

29 Porta M, Zumeta E. Implementing the Stockholm Treaty on PCPs. Occup Environ Med 2002;59:651-2.

30 Marinker $M$. Evidence and imagination. In Health targets in Europe. Polity, progress and promise. London: BM Books, 2002:1-17.

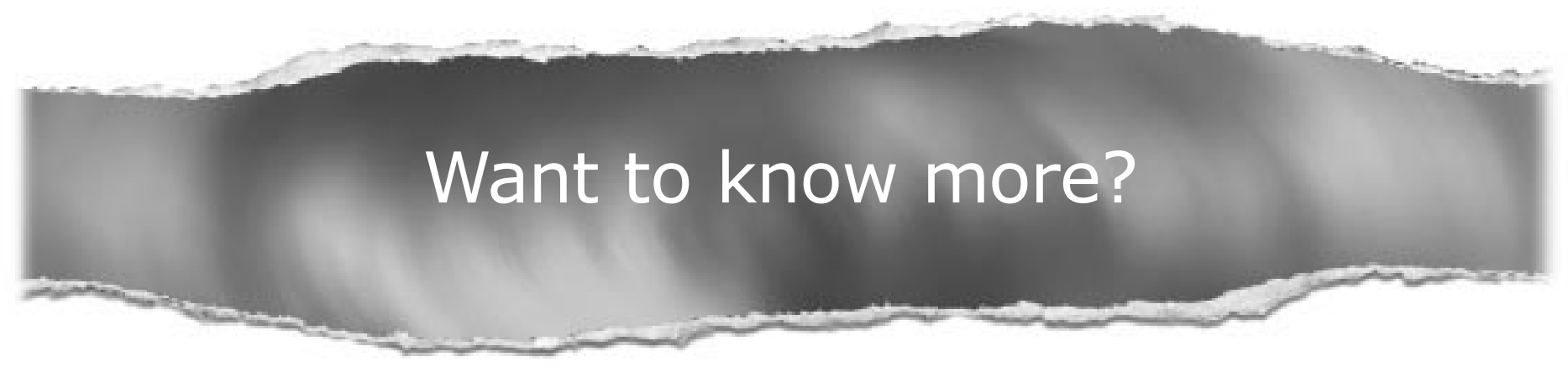

Data supplements

Limited space in printed journals means that interesting data and other material are often edited out of articles; however, limitless cyberspace means that we can include this information online.

Look out for additional tables, references, illustrations.

www.jech.com 